\title{
Sustavna psihološka i psihosocijalna podrška ženama oboljelima od raka dojke
}

1 Ljiljana Vukota

2 Lana Mužinić

1 Udruga žena oboljelih i liječenih od raka SVE za NJU

2 Klinika za psihijatriju Zdravstvenog veleučilišta, Klinička bolnica Dubrava

\section{Sažetak}

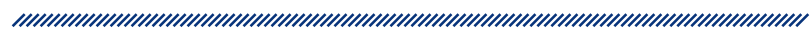

Općeprihvaćena je spoznaja o tome da psihološka i psihosocijalna podrška onkološkim bolesnicima olakšava suočavanje i prilagodbu na bolest, blagotvorno djeluje na učinak terapija te poboljšava kvalitetu života i rehabilitaciju. Rak dojke i dalje je najčešći rak u žena. Sustavna podrška može se provoditi institucionalno kroz psihoonkološke timove u klinikama koji omogućavaju ranu intervenciju nakon postavljanja dijagnoze te kroz daljnje intervencije usporedo s liječenjem od maligne bolesti ambulantnim putem. Važan su dio sustava i organizacije civilnog društva koje okupljaju pacijente s malignom bolešću u cilju davanja psihološke podrške. Navedene udruge često imaju značajnu ulogu jer predstavljaju izvaninstitucionalni oblik pružanja pomoći i podrške pa su važna podrška ženama oboljelima od raka dojke. Svi navedeni oblici podrške trebali bi biti međusobno povezani u cilju sustavnog pružanja pomoći, od otkrivanja bolesti i kroz kasnije faze liječenja. U radu se stavlja naglasak na psihološke aspekte liječenja i rehabilitacije žena oboljelih od raka dojke uz primjer dobre prakse u pružanju psihološke i psihosocijalne skrbi u skladu sa smjernicama za onkoplastično liječenje raka dojke.
Ključne riječi: psihološka podrška, rehabilitacija, rak dojke

Datum primitka: 27.08.2015.

Datum prihvaćanja: 02.10.2015.

Adresa za dopisivanje:

Ljiljana Vukota, prof. psihologije

Udruga žena oboljelih i liječenih od raka SVE za NJU

Kneza Mislava 10, Zagreb

Tel. 0913337832

E-pošta: ljiljana@svezanju.hr

\section{Uvod}

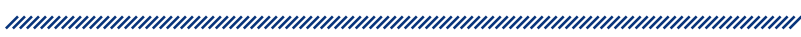

Rak dojke više se ne smatra jednom bolešću, već grupom bolesti koje se razlikuju po molekularnom subti$\mathrm{pu}^{1}$, rizičnim faktorima, kliničkim značajkama i odgovorom na tretman ${ }^{2}$. Prema podacima koje navodi American Cancer Society, Surveillance and Health Services Research, vidi se da je za 2013. očekivan broj od 232340 novih bolesnica s invazivnim karcinomom dojke te 64640 slučajeva karcinoma koji nije invazivan (tzv. in situ oblici). Također se iste godine očekivalo oko 2240 novodijagnosticiranih slučajeva raka dojke kod muškaraca².

Prema epidemiološkim podacima za posljednjih nekoliko godina, u Hrvatskoj godišnje od raka oboli više od 20000 osoba. Prema podacima Hrvatskog zavoda za javno zdravstvo, Registar za rak ${ }^{3}$, ukupan broj novodi- 
jagnosticiranih bolesnika s invazivnim rakom (šifre C00C97 MKB, bez raka kože - š. C44) bio je 20 664, i to 11219 muškaraca i 9445 žena. Gledano unutar oba spola za 2012., žene oboljele od raka dojke najbrojnija su skupina oboljela od raka (2227), a slijede muškarci oboljeli od raka traheje, bronha i pluća (2046) (Slika 1. Najčešća sijela raka u Hrvatskoj prema spolu u 2012. godini) ${ }^{3}$.

Dijagnoza i liječenje raka dojke izaziva emocionalnu traumu i istovremeno tjelesne smetnje. Emocionalna trauma dovodi do povećanog osjećaja ranjivosti, gubitka kontrole i neizvjesnosti. Kirurško, kemoterapijsko, radioterapijsko i hormonsko liječenje uzrokuje veliki broj tjelesnih $\mathrm{i}$ endokrinoloških simptoma. Važno je identificirati potrebe pacijentica radi pružanja adekvatne psihijatrijsko-psihološke podrške, tretmana i liječenja, u što je potrebno uključiti i bliske rođake i zdravstvene profesionalce. Stoga je u okviru smjernica za onkoplastično liječenje bilo potrebno razviti i psihijatrijsko-psihološki pristup i protokol tretmana pacijentica s rakom dojke ${ }^{4}$.

Veliki broj žena s emocionalnim distresom pokazuje potrebu psihološkog savjetovanja i podrške u ranim fazama bolesti ${ }^{5}$, a i tijekom kasnijih faza bolesti. Psihijatrijski poremećaji povezani su s kvalitetom života bolesnica ${ }^{6}$. Žene s uznapredovanim rakom dojke imaju visoku stopu psihijatrijskih i psiholoških poremećaja, čime je narušena kvaliteta života. Kliničari moraju pratiti psihološku prilagodbu kao dio opsežnog biopsihosocijalnog pristupa u liječenju bolesnica s rakom dojke?

U nastavku teksta prikazat će se psihički poremećaji prisutni kod bolesnica s karcinomom dojke, djelovanje stresa na njihov razvoj te važnost davanja psihološke i psihosocijalne podrške, kao i oblici pružanja takve pomoći.

\section{Psihičke teškoće kod suočavanja s dijagnozom i tijekom liječenja}

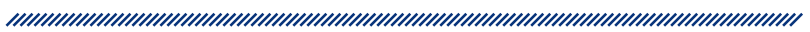

Objašnjavajući modifikaciju modela stres - bolest vulnerabilnost koja je adaptirana za potrebe bolesnika oboljelih od karcinoma autori Kornbliht i suradnici ${ }^{8}$ navode da su karcinom i liječenje definirani kao stresori, a pacijentova adaptacija kao ishod. Svojim su istraživanjem utvrdili da stresni životni događaji i socijalna podrška neovisno i značajno utječu na emocionalno stanje pacijenata, a razina socijalne podrške mora biti visoka da smanji ozbiljni psihološki distres pacijenata koji boluju od maligne bolesti ${ }^{8}$.

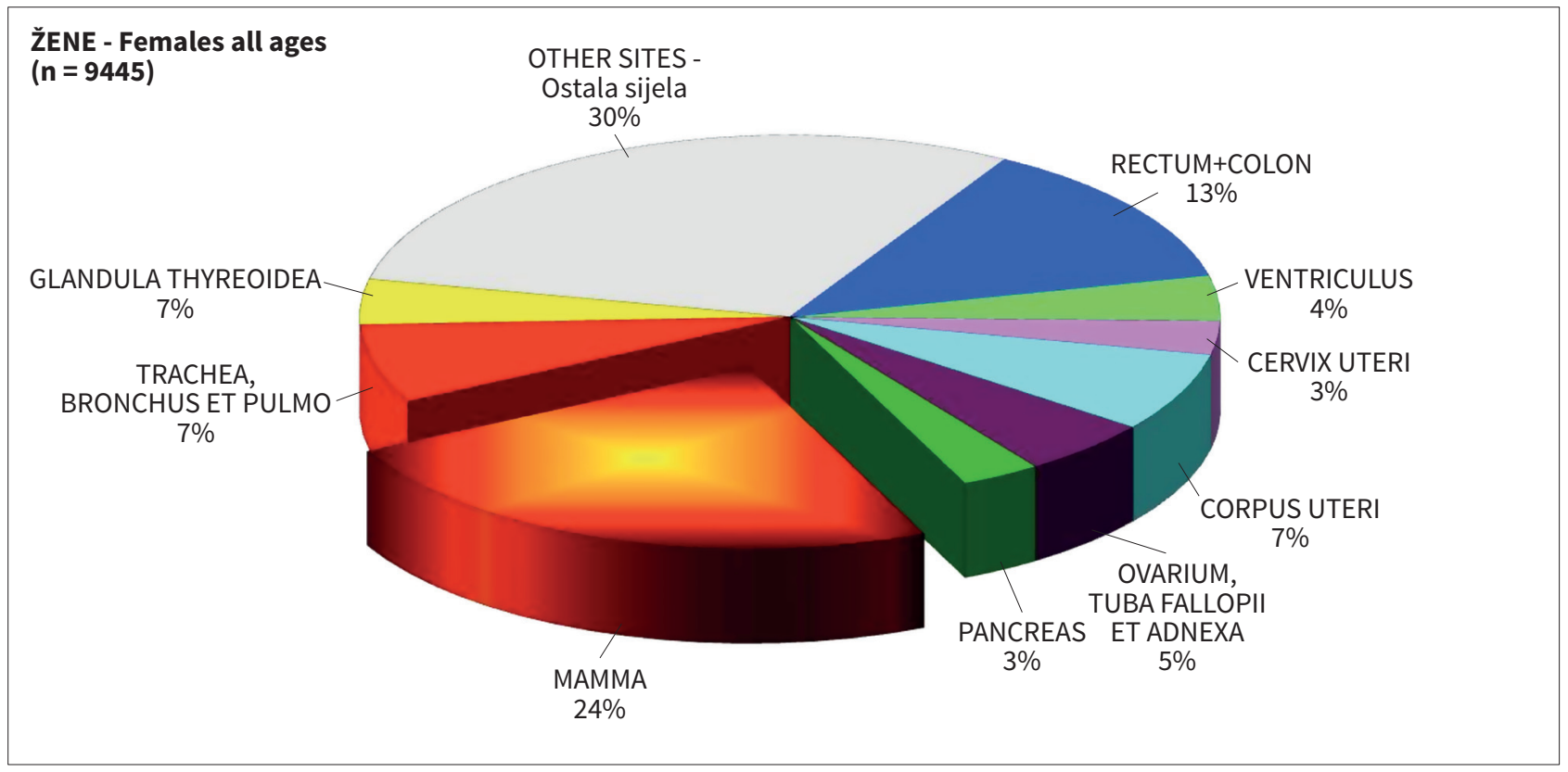


Nesporno je da svi teško oboljeli, a posebno oboljeli od raka, dijele mnoge zajedničke teškoće, a u ovom se tekstu referiramo na žene oboljele od raka dojke. U trenutku dijagnoze svaka žena proživljava duboki psihološki distres koji obilježavaju teške emocije i brojna pitanja. Iskustva su koja se opisuju kao traumatska dijagnoza sama po sebi, osjećaji nesigurnosti, strah povezan $\mathrm{s}$ operativnim zahvatima i dr. S obzirom na psihološki distres, može se javiti akutna stresna reakcija, poremećaj prilagodbe ili drugi komorbidni poremećaj kod osoba koje imaju rak dojke ${ }^{5}$.

Najčešće se kao prvi odgovor kod oboljelih javlja strah od smrti, osobito od patnje i bolnog umiranja. Uvažavajući mnoge razlike, često se susreće osjećaj bespomoćnosti, gubitka kontrole, strah za obitelj i manjak socijalne podrške. Obitelj također biva duboko pogođena dijagnozom, čak i na egzistencijalnoj razini, a ovisno o odnosima i komunikaciji, bolest može dovesti do čvršćeg povezivanja, ali i raspada. Teškoće s kojima se suočavaju članovi obitelji i njegovatelji osobito dolaze do izražaja u palijativnoj fazi ${ }^{9}$.

Kod bolesnica s recidivom bolesti uočavaju se značajne poteškoće na emocionalnom, fizičkom i funkcionalnom planu. Socijalna podrška i obiteljska podrška imaju pozitivan učinak na kvalitetu života, dok simptomi distresa, zabrinutosti, beznađa i negativnog pogleda na bolest imaju negativne učinke. Ženama s recidivom bolesti potrebno je pružiti podršku i programe koji uključuju članove obitelji, kako bi se što bolje nosili s posljedicama bolesti ${ }^{10}$.

Odgovori na malignu bolest mogu biti različiti: depresivni, projektivni i negirajući, ali među njima su brojna preklapanja i nijanse ${ }^{11}$. Teškoće suočavanja s dijagnozom raka nadmašuje jedino suočavanje $s$ recidivom, osobito ako je riječ o metastatskom raku koji se može liječiti, ali ne i izliječiti. Spoznaja izvjesnosti smrti teška je za bolesnicu i za obitelj. Integracija bolesti u svakodnevni život, prihvaćanje, odnosno vrijeme prilagodbe, razdoblje je u kojem se izmjenjuju psihička stanja u kojima mogu dominirati negacija, ljutnja, napuštenost, depresija i slična stanja.

Kao reakcija na stres u slučaju otkrivanja, a i tijekom liječenja maligne bolesti mogu se javiti određeni mehanizmi obrane kod pacijenta, poput racionalizacije, izbjegavanja, negacije i potiskivanja ${ }^{12-14}$. Tako su autori Perry, Metzger i Sigal ${ }^{15}$ u svojem istraživanju kod bolesnica s karcinomom dojke, a koje su ujedno i majke, za razliku od kontrolne skupine majki koje nemaju karcinom, utvrdili češće postojanje negacije, idealizacije, premještanja, izolacije afekta i splitinga te rjeđe korištenje altruizmom, anticipacijom i intelektualizacijom. Obrambeno funkcioniranje kod bolesnica koje su majke može također uzrokovati sekundarne efekte na funkcioniranje djeteta.

Kao reakcija na spoznaju bolesti i tijekom kasnijih faza bolesti raka dojke mogu se javiti anksioznost, poremećaj prilagodbe, depresija i posttraumatski stresni poremećaj (PTSP), ostali anksiozni poremećaji te seksualni i kognitivni poremećaji ${ }^{6,7,16}$.

Anksioznost se očituje kroz sveobuhvatan osjećaj bojazni, nemira i straha te je praćena brojnim tjelesnim reakcijama, poput napetosti, teškoća s disanjem, lupanja srca te teškoća sa spavanjem, pažnjom i koncentracijom, manjkom apetita, povećanom iritabilnošću i slično. Razvojno gledano, anksioznost je čovjeku potrebna u svrhu zaštite, no kad počne ometati svakodnevno funkcioniranje i narušava kvalitetu života, prelazi u patološku fazu i potrebna je terapija. Slično je i s depresivnim reakcijama i stanjima tuge, osamljivanjima koja ako potraju dugo mogu prerasti u pravu depresiju, a najčešće se očituju kroz sniženo raspoloženje, bezvoljnost, nedostatak snage i energije, povlačenje u sebe i izolaciju ${ }^{17}$. Psihološki problemi koji se javljaju kao posljedica spoznaje bolesti i traju tijekom liječenja, ne samo danima nego ponekad tjednima i mjesecima, mogu otežati i usporiti tijek liječenja i oporavka te je stoga dobro pravodobno intervenirati u smjeru redukcije anksioznosti i depresije.

Nisu rijetki ni problemi koji su uzrokovani manjkom obiteljske i socijalne podrške. Bolesnice su uglavnom u visokom stresu, teže se fokusiraju, obuzete su negativnim emocijama, čak i krivnjom, zabrinute za svoju egzistenciju i za egzistenciju svoje obitelji. Većinu bolest zadesi „iz čistog zdravlja“, a ponekad su obuzete ljutnjom i gorčinom, osobito kad je postupak postavljanja dijagnoze trajao dugo ili im je dijagnoza priopćena na neprimjeren način uz minimalne informacije. Prema nekim procjenama, oko $80 \%$ psihološkog i psihijatrijskog komorbiditeta koji razvijaju onkološki bolesnici ostaje neprepoznato i neliječeno te se često preklapaju, kao npr. anksioznost i depresija. Prema literaturi, prevalencija je anksioznih poremećaja kod oboljelih od raka oko $28 \%$, a pojavnost depresije kod žena oboljelih od raka dojke i do $50 \%{ }^{10}$. Mogu se razviti i simptomi posttraumatskog stresa kao reakcije na životno ugrožavajuću spoznaju maligne bolesti ${ }^{5,18}$.

Prema DSM IV ${ }^{19}$, kriteriji za dijagnosticiranje PTSP-a uključuju i obolijevanje od bolesti opasne po život kao 
potencijalne traume ${ }^{5}$. No postoje mišljenja da je klinički značaj simptomatologije PTSP-a kod pacijenata s malignom bolešću nejasan. Prema istraživanju Shelby i suradnika iz 2008. na 74 pacijentice koje su imale tumor dojke, 12 je imalo PTSP, subsindromski oblik PTSP-a imalo je pet bolesnica, dok ostatak nije imao simptoma. Pokazalo se da su bolesnice s PTSP-om imale raniju povijest trauma nasilja i anksiozne poremećaje, dok to nisu imale pacijentice sa subsindromskim oblikom PTSP-a ${ }^{20}$. Osobe s PTSP-om imale su lošije funkcioniranje i lošiju kvalitetu života ${ }^{20}$. Također, trebalo bi kritički evaluirati mogu li se subjektivni osjećaji nesigurnosti poput straha od tretmana smatrati mogućim traumatskim stresorom, a time i procijeniti je li postavljanje dijagnoze PTSP-a odgovarajuće za osobe koje imaju malignu bolest ${ }^{5}$. Prema aktualnoj kvalifikaciji DSM V, bolesti koje ugrožavaju život ili su iscrpljujuće ne smatraju se nužno traumatskima. Zdravstveni incidenti koji se kvalificiraju kao traumatski događaj uključuju iznenadne katastrofalne događaje (npr. buđenje tijekom operacije ili anafilaktički šok) ${ }^{21}$.

\section{Psihološka podrška ženama oboljelima od raka dojke}

Može li žena sama bez stručne psihološke pomoći ostvariti potrebnu stabilnost kako bi se mogla posvetiti liječenju i oporavku? Uz dobru podršku okoline neke to mogu, ali brojni primjeri ukazuju na to da velik broj žena bez stručne pomoći nije u stanju aktivirati sve vlastite resurse i održati primjerenu kvalitetu života koju objektivno narušavaju sama bolest i nuspojave terapija, ali i psihološko stanje. Neke su od njih k tome premorbidno imale značajnih psihičkih teškoća kojima je dijagnoza dodatni okidač. Kvaliteta života ogleda se u mnogim segmentima, a pojedine teškoće, kao što su psihoseksualne, teškoće s tjelesnom aktivnošću i izgledom tijela, mogu zaostati i nakon završenog liječenja. Iskustva drugih žena koje su uspješno prošle kroz liječenje i rehabilitaciju dragocjena su za oboljelu od raka dojke, ne kao recept koji će preslikati na sebe, nego kao inspiracija u pronalasku vlastitog puta. To je nešto što bolesnica može dobiti u grupama podrške uz stručno vođenje te korištenjem različitim programima koji su pokazali svoju učinkovitost u redukciji psiholoških teškoća i poboljšanju kvalitete života ${ }^{10,22,23}$.
Važnost pružanja psihološke i socijalne podrške nakon operacije karcinoma dojke vrlo je važna kroz prvu godinu nakon operacije, ali i nakon tog vremena. To se odnosi na provođenje edukacije o bolesti i davanje podrške tijekom liječenja, a posebno kod pojave mogućih problema tijekom liječenja. Kontinuitet socijalne podrške daje osjećaj sigurnosti i povjerenja te smanjuje osjećaj nesigurnosti i straha ${ }^{24}$.

U sklopu davanja podrške važne su emocionalno fokusirane strategije koje daju mogućnosti za emocionalnu ekspresiju i dobivanje emocionalne podrške ${ }^{25}$. Anksioznost može utjecati na kvalitetu života bolesnika i zato rad na smanjenju anksioznosti može biti ključna komponenta za poboljšanje kvalitete života bolesnica s tumorom dojke te rad na psihološkim potrebama može doprinijeti ublažavanju anksioznosti ${ }^{26}$.

Suportivnom terapijom pomaže se u smanjenju anksioznosti i depresivnosti, a smanjenje ovih smetnji djeluje na poboljšanje stanja onkoloških bolesnika, pa tako i žena s rakom dojke, a time utječe i na kvalitetu života u cjelini. Psihoonkološkim pristupom ostvaruje se značajan učinak i na tjelesnoj i na psihičkoj razini bolesnika27.

U svijetu postoje razne udruge i savjetovališta koja daju podršku ženama oboljelima od karcinoma. Kao jedan od primjera u SAD-u ističemo društvo American Cancer Society, koje pomaže bolesnicama da se dobro nose $\mathrm{s}$ bolešću na način da ih se ohrabruje kroz faze bolesti, da im se objasni koje su tretmanske opcije, pruža im se emocionalna podrška te su im 24 sata dnevno dostupne korisne informacije².

Sa psihološke strane uloga stručnjaka jest da zajedno s oboljelom pronađu način i put da u procesu cijeljenja otkriju i u prvi plan postave njezine zdrave i jake stane, zaštitne čimbenike i ključne bliske osobe. Žene koje su u tome uspjele kažu da ih je rak promijenio nabolje, kao da im je dao neku snagu i vjeru u sebe, neku mudrost koju prije nisu imale. Upravo te žene, uz dodatno educiranje i superviziju stručnjaka, mogu biti kvalitetan primjer, „mentorice“ i uzori onima koje su na pragu svojeg liječenja i potrebno im je ohrabrenje. 


\section{Iz Kliničkih smjernica za onkoplastično liječenje raka dojke}

Smjernice za onkoplastično liječenje raka dojke u Hrvatskoj donose veliku novost upravo u dijelu psihosocijalne skrbi za bolesnicu. U okviru multidisciplinarnog tima za dojku definirana su tri tima: dijagnostički, terapijski i rehabilitacijski, kao novi tim koji čine psihijatar i psihologeg.

Ovakav način rada otvara mogućnost detekcije izrazito vulnerabilnih bolesnica kojima nije potrebna samo kraća intervencija nego i psihološka i psihijatrijska dijagnostika te kontinuirani tretman u svrhu multidisciplinarne rehabilitacije.

Spoznaja dijagnoze raka dojke nosi sa sobom i mnoge druge spoznaje o sebi i životu koje su, kao i sama dijagnoza, opterećene dubokom tjeskobom i neizvjesnošću. lako se to može reći za sve teške i često smrtne bolesti, rak dojke ima brojne posebnosti radi značaja koje dojke imaju u životu svake žene. Važno je da svi koji sudjeluju u liječenju u ženi vide cjelovitu osobu, a ne samo bolesnicu. Partnerstvo žene u timu koji liječi rak dojke povećava njezinu motivaciju, povjerenje, suradljivost i posvećenost liječenju. $U$ tom je timu nužna prisutnost psihologa ili/i psihijatra, kako bi se realizirala ideja o iscjeljenju žene kao cjelovite osobe, a ne samo bolesti. U širem je smislu dio tog tima i njezina obitelj ili barem jedna bliska, ključna osoba iz njezina života koja će je podupirati kad je obuzme strah ili malodušnost. Vjera u vlastito liječenje jača je ako žena upozna druge žene koje su se uspješno izliječile, zadržale kvalitetu života, a možda tijekom i poslije liječenja stvorile nove vrijednosti i presložile životne prioritete.

Svaki je postupak koji pridonosi boljoj informiranosti, većoj stabilnosti, motiviranosti i suradljivosti u liječenju dobrodošao i potreban, jer se sve to pozitivno reflektira na tijek liječenja i rehabilitaciji.

Dijagnoza i liječenje raka dojke izaziva emocionalnu traumu $\mathrm{i}$ istovremeno tjelesne smetnje. Emocionalna trauma dovodi do povećanog osjećaja ranjivosti, gubitka kontrole i neizvjesnosti. Kirurško, kemoterapijsko, radioterapijsko i hormonsko liječenje uzrokuje veliki broj tjelesnih $\mathrm{i}$ endokrinoloških simptoma. Važno je identificirati potrebe pacijentica radi pružanja adekvatne psihijatrijsko-psihološke podrške, tretmana i liječenja, u što je potrebno uključiti i bliske rođake i zdravstvene profesionalce. Stoga je bilo potrebno u Smjernicama razviti psihijatrijsko-psihološki pristup i protokol tretmana pacijentica s rakom dojke ${ }^{4}$.

U prvom dijelu navedenog protokola važno je identificirati emocionalno najvulnerabilnije bolesnice, što se odnosi na emocionalne smetnje i kvalitetu života te njihove načine sučeljavanja s bolešću (mehanizme obrane). Emocionalni se distres kod žena operiranih od raka dojke najčešće javlja tri do sedam mjeseci nakon dijagnoze, a najveće se promjene u prilagodbi zbivaju između četvrtog i trinaestog mjeseca te je stoga potrebno provoditi kontinuiranu dijagnostiku. Provodi se psihijatrijska i psihološka procjena i pregled te se postavlja dijagnoza prema vrijedećim dijagnostičkim kriterijima, uz procjenu kvalitete života primjenom upitnika ${ }^{4}$.

$\mathrm{U}$ drugom dijelu protokol definira rehabilitaciju kao proces oporavljanja. $U$ inicijalne intervencije uključene su psihoedukacija koja se odnosi na pacijenticu i njezinu obitelj uz razvoj motivacije za liječenje, pružanje savjetovanja, psihoterapijske podrške, kratkotrajne psihoterapije i psihofarmakološkog liječenja te koordinacija psihosocijalne pomoći. U kontinuirane intervencije uključene su dugotrajna psihoterapija: individualna, grupna i obiteljska, tjelesne aktivnosti / vježbanje, grupe podrške, tehnike relaksacije i razne aktivnosti: ples, šetnja, hobi i sl. Zadnji dio protokola odnosi se na rad s medicinskim timom, a uključuje edukaciju, osvještavanje i razumijevanje vlastitih osjećaja prema pacijentu, razumijevanje psiholoških i psihičkih komplikacija bolesti, emocionalnih reakcija na bolest te rad s kontratransfernim reakcijama. Provoditelji su intervencija psihijatar, psiholog, socijalni pedagog ili drugi educirani stručnjaci ${ }^{4}$.

Smjernice obuhvaćaju psihološku potporu ženama oboljelima od raka u timu za dojku nakon dijagnoze, tijekom liječenja i oporavka te ulogu psihologa ${ }^{29}$. U timu za dojku psiholog i psihijatar međusobno se konzultiraju i timu prezentiraju zajedničko mišljenje. Kod postavljanja dijagnoze i predoperativnih priprema bolesnicu je potrebno uputiti psihologu, koji će je pratiti tijekom hospitalizacije, a prije otpusta dati procjenu o potrebama za daljnjim praćenjem ili tretmanom. $U$ tretmanu psihologa ili psihijatra uz bolesnicu mogu biti članovi obitelji. Psiholog ili psihijatar mogu predložiti nastavak tretmana u izvanbolničkim programima, odnosno u zajednici u organizacijama civilnog društva koje provode programe pružanja psihosocijalne podrške oboljelima i obitelji. Psiholog i psihijatar ravnopravni su članovi tima koji međusobno usuglašavaju mišljenje, a tko će od njih biti više angažiran ovisi o organizacijskim mogućnostima bolnice i potrebama bolesnice. 


\section{Uloga udruga u davanju psihološke pomoći oboljelima od raka - primjer dobre kliničke prakse: Centar za psihološku pomoć Udruge SVE za NJU}

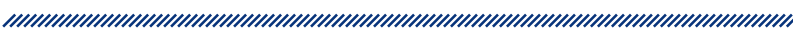

Psihološka podrška može se pružati i kroz organizacije civilnog društva koje okupljaju pacijente s malignom bolešću u cilju davanja psihološke podrške. Ovdje kao primjer dobre prakse navodimo djelovanje Udruge SVE za NJU koja u Hrvatskoj djeluje od 2008., a od 2010. kroz Centar za psihološku pomoć ženama oboljelima od raka pruža stručnu psihološku pomoć oboljelim ženama i njihovim obiteljima. Udruge predstavljaju oblik pružanja pomoći i podrške oboljelim ženama u zajednici i važna su karika u prevenciji ${ }^{30}$.

Centar je mjesto na kojem žena pronalazi iskustva drugih pacijentica integrirana sa znanjima stručnjaka, primarno psihologa. To je mjesto na kojem će dobiti odgovore na mnoga pitanja, upoznati druge žene i moći u sigurnom okruženju razgovarati o svemu. Članovi obitelji mogu se javiti i naučiti kako biti najbolja podrška bolesnici. Iznimno je važno da je obiteljsko okruženje podržavajuće, da drugi članovi preuzmu na sebe neke uloge i obveze. Oni se ponekad i sami teško nose sa situacijom i potrebna im je poduka, ali i osobna psihološka podrška kako bi se lakše nosili s bolešću bliske osobe kroz sve faze liječenja ${ }^{31}$. Ovo posebno dolazi do izražaja u procesu žalovanja ${ }^{32}$.

U Centru se mogu sresti žene koje su izliječene i žene u različitim fazama liječenja. Potrebno im je povratiti malo moći i kontrole u život, preuzeti aktivnu ulogu. Čim se krene s liječenjem, kao da se krenulo u borbu ${ }^{33}$. Prema vremenu u kojem najčešće dolaze u Centar potražiti psihološku i psihosocijalnu pomoć razvidno je nekoliko najčešćih kritičnih točaka u procesu liječenja: nošenje $s$ dijagnozom u prvim trenutcima, priprema za operaciju i prihvaćanje opsega operacije, donošenje odluke o prihvaćanju predloženog liječenja, gubitak vjere u učinak terapija koje su u tijeku te završetak liječenja i povratak u sve životne uloge, osobito povratak na posao. Naravno, iznimno je kritična točka povrat bolesti ili prelazak u metastatsku bolest. Žene se javljaju i nakon nekoliko godina od završetka liječenja jer je njihov život i dalje prožet tjeskobom i strahom od mogućeg povrata bolesti.

Vrlo je važno da na jednom mjestu dobiju pouzdane informacije o bolesti, liječenju, prehrani i drugim temama te informacije povezane s mogućnostima rekonstrukci- je dojke ${ }^{34}$. Psihološka pomoć u Centru strukturirana je u četiri glavna programa i odnosi se na psihološke tretmane, savjetovališta, edukacijsko-terapijske programe i smještaj u Centru. Raznovrsnost programa važna je radi sveobuhvatne skrbi i zadovoljavanja različitih potreba oboljelih ${ }^{35}$. Psihološki su tretmani organizirani kao psihoedukacija, individualno savjetovanje $\mathrm{i}$ psihoterapija, partnerski i obiteljski tretmani te grupe podrške. Članovi obitelji također se uključuju i u individualnu psihološku terapiju. Komorbidni poremećaju sreću se kod oboljelih, ali i kod članova obitelji36. Grupni tretman odvija se u malim grupama do 12 korisnica uz dva terapeuta.

Savjetovališta za oboljele i liječene žene organizirano je kroz četiri oblika: pravno savjetovalište o pravima pacjenata i drugim pravima te pomoći u njihovu ostvarivanju, savjetovalište medicine rada, svjetovalište za prehranu i telefonsko savjetovalište. Pravilna je prehrana važna u svim fazama liječenja i kao prevencija bolesnih stanja. Intervencije u prehrani prije su pravilo nego izuzetak i važno je da ih vodi stručnjak. Ovo je jednostavan način za ženu da donekle vrati kontrolu u svoj život i da aktivno participira u liječenju. Telefonsko savjetovanje provodi se kao krizna intervencija ili kao kontinuirani psihološki tretman za žene iz udaljenijih mjesta. U svakom savjetovalištu usluge pružaju stručnjaci (pravnici, specijalisti medicine rada, nutricionisti i psiholozi).

Edukacijsko-terapijski programi organizirani su kroz predavanja psihologa, onkologa, radiologa, kirurga, anesteziologa, fizijatara i dr. u otvorenim grupama sa svrhom edukacije o bolesti i liječenju. Važan oblik edukacije provodi se i kroz tiskane eduktivne knjižice ${ }^{37}$. Psihoedukacija se organizira u ciklusima kao zasebni program te kao dopuna individualnim i grupnim terapijama, a oboljele se potiče na primjerenu tjelesnu aktivnost i poučava tehnikama relaksacije ${ }^{22}$.

Posebna se važnost pridaje superviziji terapeuta. Terapeuti koji čine stalni terapijski tim imaju organiziranu mjesečnu grupnu superviziju s ciljem osobnog i profesionalnog rasta $^{38}$. lako supervizija ima terapijski učinak na članove, njezina je primarna uloga profesionalni rast i razvoj pomagača kroz superviziju konkretnih slučajeva, što dovodi do unaprjeđivanja terapijskog rada i kvalitete usluge ${ }^{39}$. 


\section{Rasprava}

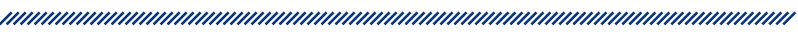

Najvažnije je da bolesnica pravodobno dobije sve bitne informacije i da izvor informacija bude pouzdan, stručan i kvalitetan ${ }^{40}$. Neselektivno informiranje na internetu ili kod drugih nepouzdanih izvora ili osoba često ima za posljedicu još veći strah i zbunjenost kod oboljele. Rezultat toga može biti poljuljano povjerenje u vlastito liječenje, odabir terapija i očekivani ishod. Kvalitetan izvor informacija nije samo kirurg ili onkolog nego i educirana medicinska sestra, psiholog, psihijatar ili drugi stručnjak u ulozi volontera ili profesionalca. Posebno educirani volonteri u udrugama također mogu biti dobar izvor informacija, osobito na području davanja informacija i korisnih praktičnih savjeta. Stoga je zadaća svih uključenih u liječenje da bolesnicu upute u dobro savjetovalište (bolničko ili izvanbolničko) stručnjacima s područja psihoonkologije i mentalnog zdravlja (psiholozi, psihijatri i drugi educirani profesionalci).

Potrebno je istaknuti medicinske sestre koje su iznimno važne bolesnicama i obitelji, ne samo u području skrbi u užem smislu nego i u području informiranja, savjetovanja, podrške za prihvaćanje liječenja te stvaranja ozračja optimizma i osjećaja sigurnosti ${ }^{41}$. Liječnici u primarnoj zaštiti nezaobilazni su u prepoznavanju simptoma bolesti i ranom otkrivanju, ali i u saniranju brojnih nuspojava liječenja i praćenju. To se osobito odnosi na liječnika obiteljske medicine koji najbolje poznaje bolesnicu, ali poznaje i obiteljsku situaciju te zna kakvu podršku bolesnica ima u obitelji.

Žene oboljele od raka, kao, uostalom, i drugi bolesnici, izložene su stalnim pretragama, muči ih neizvjesnost kakvi će biti rezultati, ne poznaju dovoljno dobro zdravstveni sustav i ne snalaze se u njemu, anksiozne su i pojačano osjetljive. Na svojem putu liječenja i kontrola dolaze u kontakt sa zdravstvenim osobljem različitih specijalnosti i razina. Iznimno je važno da i zdravstveni djelatnici imaju barem najosnovnije spoznaje o stanju takvih bolesnika i načinima komunikacije jer su uključeni u proces njihova liječenja u širem smislu. Također je važno da imaju spoznaju o svojevrsnoj moći i utjecaju koju imaju na bolesnike koji o njima na neki način ovise. Tim se utjecajem moraju koristiti odgovorno. Stoga je od posebnog značaja edukacija medicinskog osoblja svih razina i specijalnosti u ovom području. S tom je edukacijom u teorijskom, praktičnom i iskustvenom smislu potrebno započeti u procesu školovanja zdravstvenih radnika ${ }^{42}$.
Osim zdravstvenih radnika, u proces liječenja i rehabilitacije uključeni su (ili bi trebali biti) stručnjaci različitih zanimanja, kao što su psiholozi, socijalni radnici, radni terapeuti, socijalni pedagozi, nutricionisti, ali i osobe drugih profesija koje imaju vještine važne za očuvanje i unaprjeđivanje postojećih resursa i potencijala oboljele. Njihov se angažman u liječenju i rehabilitaciji može odvijati u drugim institucijama ili u okviru zajednice, čega su svakako dio i organizacije civilnog društva. Mnoge podupiruće aktivnosti i različiti oblici savjetovanja mogu se i moraju organizirati u zajednici. To je izvrstan način da bolesnik osjeti brigu zajednice i da ostane socijalno uključen. Volonterstvo je dobrodošlo kad govorimo o izvanbolničkim tretmanima. Volonteri mogu biti stručnjaci i laici, ali svima im je u nekoj mjeri potrebna edukacija u području komunikacije i psihoonkologije kao nadogradnja njihovim bazičnim znanjima ${ }^{43}$.

Psihologija, posebno zdravstvena psihologija (uz kliničku i neke druge grane) kao znanstvena i primijenjena disciplina ima velike zadaće u brizi za mentalno zdravlje i zaštitu mentalnog zdravlja u zajednici, što uključuje pružanje podrške ranjivim osobama, među kojima su onkološki i palijativni bolesnici i njihove obitelji4 Psiholozi osim neposredne pomoći moraju pridonijeti $\mathrm{i}$ istraživačkim radom u ovome području, kreiranju programa, edukaciji stručnjaka i evaluaciji programa, naravno, velikim dijelom u suradnji s drugim strukama, osobito psihijatrima. Važno je osigurati komplementarnost programa i stručnjaka te omogućiti bolesniku ostvarivanje holističkog i personaliziranog pristupa uz koordinaciju i informiranje korisnika o vrsti usluga koje mogu dobiti u pojedinim organizacijama u zajednici i institucijama. To se možda najbolje oslikava u području palijativne skrbi, gdje je osobito važno koordinirati postojeće resurse u brizi za konkretnog bolesnika kako bi se ublažila patnja bolesnika i obitelji te sačuvala kvaliteta života bolesnika koliko je god to moguće. 


\section{Zaključak}

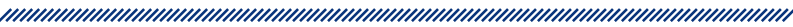

Iz iskustva rada s bolesnicama te pregledom literature o psihičkim poremećajima koji su najčešći kod žena oboljelih od raka zaključujemo da je iznimno važno rano prepoznavanje poremećaja i rana intervencija. Psihološka i psihosocijalna podrška koju pružaju educirani stručnjaci pridonosi stabilizaciji bolesnice, suradljivosti, rezultatima liječenja, boljem nošenju sa stresom od bolesti, boljoj prilagodbi, rehabilitaciji i povratku u sve životne uloge. U organizaciji psihološke podrške potrebno je slijediti određene standarde i smjernice te je stoga važno da u ovom području postoje, zasad samo za rak dojke, smjernice koje daju okvir za organizaciju konzultativno-suradne psihijatrije i psihologije. Suradnjom zdravstvenih ustanova i organizacija civilnog društva koje imaju organizirane programe za pružanje stručne podrške moguće je veliki dio potpore pružiti izvanbolnički, u zajednici. Važno je da programi budu kompatibilni i da se nadopunjuju s postupcima u bolnici, kako bi se ekonomičnije iskoristili resursi. $\mathrm{S}$ bolnicom povezujemo dijagnostiku i liječenje, a suportivni se dio može obaviti u programima u zajednici. Naravno, bolesnice se u svakom trenutku u skladu s potrebama mogu iz programa u zajednici uputiti u ambulantu $\mathrm{i}$ obratno. To je moguće za one bolesnice koje imaju osigurano kontinuirano praćenje. Kao primjer dobre prakse izložen je model rada Centra za psihološku pomoć Udruge SVE za NJU. Sa stajališta napora da se što prije postavi dijagnoza i započne liječenje važno je da se u jednako kratkom roku osigura psihološka podrška bolesnici i obitelji. Informacije o mogućnostima pružanja takvih usluga trebale bi bolesnicama biti dostupne već kod postavljanja dijagnoze.

\section{Literatura}

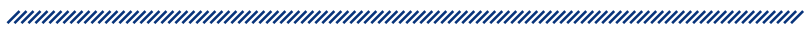

1. Perou CM, Sørlie T, Eisen MB, van de Rijn M, Jeffrey SS, Rees CA, Pollack JR, Ross DT, Johnsen H, Akslen LA et al. Molecular portraits of human breast tumours. Nature. 2000;406(6797):747-752.

2. American Cancer Society. Breast Cancer Facts \& Figures 2013-2014. Atlanta: American Cancer Society, Inc. 2013.

3. Hrvatski zavod za javno zdravstvo, Registar za rak. Incidencija raka u Hrvatskoj 2012. Bilten 37. Zagreb, 2014. Dostupno na:http://www.hzjz.hr/wp-content/uploads/2013/11/ Bilten-2012_final.pdf (pristupljeno 20.07.2015.)

4. Kozarić-Kovačić D. Psihijatrijsko-psihološki pristup i protokol tretman pacijentica s rakom dojke. U: Stanec Z, Vlajčić Z, ur. Kliničke smjernice za onkoplastično liječenje raka dojke. Zagreb: Klinika za plastičnu, rekonstrukcijsku i estetsku kirurgiju Medicinskog fakulteta Sveučilišta u Zagrebu; 2013:21-23.

5. Mehnert A, Koch U. Prevalence of acute and post-traumatic stress disorder and comorbid mental disorders in breast cancer patients during primary cancer care: a prospective study. Psychooncology. 2007;16(3):181-188.

6. Okamura M, Yamawaki S, Akechi T, Taniguchi K, Uchitomi Y. Psychiatric disorders following first breast cancer recurrence: Prevalence, associated factors and relationship to quality of life. Japanese Journal of Clinical Oncology. 2005;35(6):302-309.

7. Grabsch B, Clarke DM, Love A, McKenzie DP, Snyder RD, Bloch S, Smith G, Kissane DW. Psychological morbidity and quality of life in women with advanced breast cancer: a cross-sectional survey. Palliative \& Supportive Care. 2006;4(1):47-56.

8. Kornblith $A B$, Herndon JE, Zuckerman E, Viscoli CM, Horwitz RI, Cooper MR, Harris L, Tkaczuk KH, Perry MC, Budman D, Norton LC, Holland J. Social support as a buffer to the psychological impact of stressful life events in women with breast cancer. Cancer. 2001;91(2):443-454.

9. Grunfeld E, Coyle D, Whelan T, Clinch J, Reyno L, Earle CC, Willan A, Viola R, Coristine M, Janz T, Glossop R. Family caregiver burden: results of a longitudinal study of breast cancer patients and their principal caregivers. Canadian Medical Association Journal. 2004;170(12):1795-1801.

10. Northouse LL, Mood D, Kershaw T, Schafenacker A, Mellon S, Walker J, Galvin E, Decker V. Quality of life of women with recurrent breast cancer and their family members. Clinical Oncology. 2002;20(19):4050-4064.

11. Anton S, Mrđenović S, Gugić D. Psihodinamski pristup oboljelima od karcinoma. Osijek: Svjetla grada; 2012.

12. Bahnson CB, Bahnson MB. Role of the ego defenses: denial and repression in the etiology of malignant neoplasm. Annals of the New York Academy of Sciences. 1966;125(3):827-845.

13. Goldstein D, Antoni M. The distribution of repressive coping styles among non-metastatic and metastatic breast 
cancer patients as compared to non-cancer patients. Psychology and Health. 1989;3(4):245-258.

14. Stiefel F. Comment on Understanding why women delay in seeking help for breast cancer symptoms. Journal of Psychosomatic Research. 2006;60(3):309-10.

15. Perry JC, Metzger J, Sigal JJ. Defensive Functioning Among Women With Breast Cancer and Matched Community Controls. Psychiatry. 2015;78(2):156-69.

16. Kissane DW, Grabsch B, Love A, Clarke DM, Bloch S, Smith GC. Psychiatric disorder in women with early stage and advanced breast cancer: a comparative analysis. The Australian and New Zealand Journal of Psychiatry. 2004;38(5):320-326.

17. Miller K, Massie MJ. Depression and anxiety. Cancer Journal. 2006;12(5):388-397.

18. O'Connor M, Christensen S, Jensen AB, Møller S, Zachariae R. How traumatic is breast cancer? Post-traumatic stress symptoms (PTSS) and risk factors for severe PTSS at 3 and 15 months after surgery in a nationwide cohort of Danish women treated for primary breast cancer. British Journal of Cancer. 2011;104(3):419-426.

19. Dijagnostički i statistički priručnik za duševne poremećaje. Četvrto izdanje. Jastrebarsko: Naklada Slap; 1996.

20. Shelby RA, Golden-Kreutz DM, Andersen BL. PTSD diagnoses, subsyndromal symptoms, and comorbidities contribute to impairments for breast cancer survivors. Journal of Traumatic Stress. 2008;21(2):165-172.

21. Dijagnostički i statistički priručnik za duševne poremećaje. Peto izdanje. Jastrebarsko: Naklada Slap; 2014.

22. Kashani F, Babaee S, Bahrami M, Valiani M. The effects of relaxation on reducing depression, anxiety and stress in women who underwent mastectomy for breast cancer. Iranian Journal of Nursing and Midwifery Research. 2012;17(1):30-3. Dostupno na: http://www.ncbi.nlm.nih. gov/pubmed/23493112 (pristupljeno 20.07.2015).

23. Mohabbat-Bahar S, Maleki-Rizi F, Akbari ME, Moradi-Joo M. Effectiveness of group training based on acceptance and commitment therapy on anxiety and depression of women with breast cancer. Iranian Journal of Cancer Prevention. 2015;8(2):71-6. Dostupno na: http://www.ncbi.nlm.nih. gov/pubmed/25960844 (pristupljeno 21.07.2015).

24. Drageset S, Lindstrøm TC, Giske T, Underlid K. Women's experiences of social support during the first year following primary breast cancer surgery. Scandinavian Journal of Caring Sciences. 2015; [Epub ahead of print].

25. Reynolds P, Hurley S, Torres M, Jackson J, Boyd P, Chen VW. Use of coping strategies and breast cancer survival: results from the Black/White Cancer Survival Study. American Journal of Epidemiology. 2000;152(10):940-949.

26. Akechi T, Momino K, Miyashita M, Sakamoto N, Yamashita H, Toyama T. Anxiety in disease-free breast cancer patients might be alleviated by provision of psychological support, not of information. Japanese Journal of Clinical Oncology. 2015;45(10):929-33.

27. Peharda T. Multidisciplinarni pristup onkološkim pacijentima u OB Pula. Glasnik pulske bolnice. 2009;5(2):140-2.
28. Stanec Z, Vlajčić Z, ur. Kliničke smjernice za onkoplastično liječenje raka dojke. Zagreb: Klinika za plastičnu, rekonstrukcijsku i estetsku kirurgiju Medicinskog fakulteta Sveučilišta u Zagrebu; 2013.

29. Vukota L. Smjernice za psihološku potporu ženama oboljelima od raka u Timu za dojku. U: Stanec Z, Vlajčić Z, ur. Kliničke Smjernice za onkoplastično liječenje raka dojke. Zagreb: Klinika za plastičnu, rekonstrukcijsku i estetsku kirurgiju Medicinskog fakulteta Sveučilišta u Zagrebu; 2013.

30. Azenha G, Bass LP, Caleffi M, Smith R, Pretorius L, Durstine $A$, Perez CP. The role of breast cancer civil society in different resource settings. Breast. 2011;Suppl. 2:S81-7.

31. Nakaya N, Saito-Nakaya K, Bidstrup PE, Dalton SO, Frederiksen K, Steding-Jessen M, Uchitomi Y, Johansen C. Increased risk of severe depression in male partners of women with breast cancer. Cancer. 2010;116(23):5527-5534.

32. Arambašić L. Gubitak, tugovanje, podrška. Jastrebarsko: Naklada Slap; 2005.

33. Holland J, Lewis S. The Human Side of Cancer. Living with Hope, Coping with Uncertainty. New York: Harper; 2000.

34. Vukota L. Psihološka pomoć tijekom liječenja i oporavka. U: Ahčan U, ur. Rak dojke i suvremeni načini rekonstrukcije. Zagreb: Medicinska naklada i Sve za nju; 2015:276-278.

35. Kovács Z, Szabó C, Fülöp E. Therapy helps - psychosocial support for patients diagnosed with breast cancer, reducing anxiety and depression. Psychiatria Hungarica. 2013;28(4):454-63. Dostupno na: http://www.ncbi.nlm. nih.gov/pubmed/24443579 (pristupljeno 20.07.2015.).

36. Braš M. Dijagnostika i liječenje komorbiditetnih psihijatrijskih poremećaja bolesnika i članova obitelji. U: Jušić A, Braš M, Lončar Z, ur. Hospicij i palijativna skrb - osnovno ljudsko pravo. Zagreb: Hrvatsko društvo za hospicij/ palijativnu skrb; 2008:163-176.

37. Anticancer Fund, European Society for Medical Oncology. Rak dojke: vodič za bolesnice. Dostupno na: http://www.esmo. org/content/download/65113/1174049/file/ESMO-ACF-RakDojke-Vodic-za-Bolesnice.pdf (pristupljeno 20.07.2015.)

38. Bezić I. Timska supervizija. U: Ajduković M, Cajvert L, ur. Supervizija u psihosocijalnom radu. Zagreb: Društvo za psihološku pomoć; 2004:281-301.

39. Ajduković M. Određenje grupne supervizije. U: Ajduković M, Cajvert L, ur. Supervizija u psihosocijalnom radu. Zagreb: Društvo za psihološku pomoć; 2004:121-155.

40. Mills ME, Sullivan K. The importance of information giving for patients newly diagnosed with cancer: a review of the literature. Journal of Clinical Nursing. 1999;8(6):631-642.

41. Ljubas A, Anđelić M. Person - centered nursing. U: Đorđević $\mathrm{V}$, Braš $\mathrm{M}$, Miličić $\mathrm{D}$, ur. Person in medicine and healtcare. Zagreb: Medicinska naklada; 2012:375-381.

42. Đorđević V, Braš M. Komunikacija u medicini. Zagreb: Medicinska naklada; 2011.

43. Prstačić M, Sabol R. Psihosocijalna onkologija i rehabilitacija. Zagreb: Medicinska naklada; 2006.

44. Božičević V, Brlas S, Gulin M, ur. Psihologija u zaštiti mentalnog zdravlja, Prijedlog smjernica za psihološku djelatnost u zaštiti i promicanju mentalnog zdravlja. Virovitica: Zavod za javno zdravstvo Sveti Rok Virovitičko-podravske županije; 2011. 


\section{SYSTEMATIC PSYCHOLOGICAL AND PSYCHOSOCIAL SUPPORT FOR WOMEN WITH BREAST CANCER}

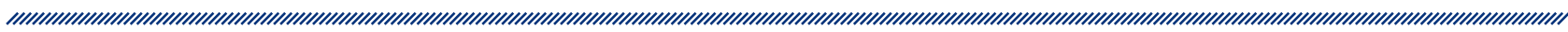

1 Ljiljana Vukota

2 Lana Mužinić

1 Association EVERYTHING for HER (CSO)

2 Department of Psychiatry, University Hospital Dubrava ing from breast cancer with an example of good practice in the provision of psychological and psychosocial care in accordance with the guidelines for oncological and plastic surgery treatment of breast cancer.

\begin{abstract}

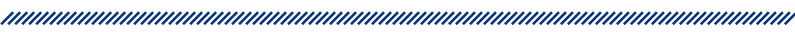

The generally accepted knowledge about psychological and psychosocial support of oncology patients facilitates coping and adaptation to the disease, it is beneficial for the effect of therapy and improves the quality of life and rehabilitation. Breast cancer is still the most common cancer in women. Systematic support can be carried out through institutional psycho-oncological teams in clinics that provide early intervention after diagnosis, and through further interventions simultaneous with the treatment of the malignant disease in the outpatient treatment. An important part of the system are civil society organizations that bring together patients with malignant diseases with the aim of providing psychological support. These organizations often play a significant role because they represent non-institutional forms of assistance and support and are thus an important support for women suffering from breast cancer. All these forms of support should be interconnected with the aim of systematic assistance from the detection of the disease and through later stages of the treatment. The paper focuses on the psychological aspects of treatment and rehabilitation of women suffer-
Keywords: psychological support, rehabilitation, breast cancer 